\title{
A ALEGRIA PARADOXAL: O RISO CARNAVALESCO COMO FILOSOFIA TRÁGICA
}

\section{Paradoxal joy: riso carnavalesco as a tragic philosophy}

Kátia Vanessa Tarantini SILVESTRI ${ }^{1}$

\begin{abstract}
Resumo: A alegria paradoxal é tema deste artigo. Uma ligação é feita entre os movimentos populares e protestos ocorridos desde 2013 no Brasil com o conceito de carnavalização, alegria paradoxal e a filosofia trágica. O corpus se compõe de um exemplo de manifestação popular; de uma análise de um discurso humorístico (stand up) e de análise de um programa de humor televisivo. A metodologia adotada é a dialógica de cotejamento, na qual tudo dialoga com tudo. O entendimento da ligação entre política inorgânica e carnavalização terá sua fundamentação na filosofia trágica e na alegria paradoxal. A carnavalização e ambivalência do riso carnavalesco são defesa de uma política inorgânica nas entranhas das manifestações populares.
\end{abstract}

Palavras-chave | Metodologia bakhtiniana. Movimentos populares. Política inorgânica.

\begin{abstract}
Paradoxical joy is the theme of this article. A connection is made between the popular movements and protests that occurred since 2013 in Brazil with the concept of carnivalization, paradoxical joy and tragic philosophy. The corpus is composed of an example of popular manifestation; an analysis of a humorous speech (stand up) and analysis of a television humor program. The methodology adopted is the dialogue of collating, in which everything dialogues with everything. The understanding of the link between inorganic politics and carnivalization will be grounded in tragic philosophy and paradoxical joy. The carnivalization and ambivalence of carnival laughter is the defense of an inorganic politics in the bowels of the popular demonstrations.
\end{abstract}

Keywords | Bakhtinian methodology. Popular movements. Inorganic politics.

1 Silvestri. Uniararas. Endereço eletrônico: katiavanessa@uniararas.br 
- A alegria paradoxal: o riso carnavalesco como filosofia trágica

\section{Para início de conversa}

Problematizar a alegria é o principal objetivo deste texto. Como se lê no título, a argumentação é a condição paradoxal da alegria. Que paradoxo é esse? A alegria aqui defendida é tanto responsiva e realista quanto lúdica: é uma alegria que escapa a uma causa específica, pois é a própria existência a sua razão, é uma alegria infuncional. O regozijo do existir, e aqui se encontra o crucial, coincide com o fato de ser a existência o que há de menos regozijador.

Pautar a reflexão acerca da alegria paradoxal na linha trágica do pensamento filosófico (NIETZSCHE, 1987, 2013a, 2013b, 2013c; BAKHTIN, 2006, 2010a, 2010b, 2011; ROSSET, 1989, 2000) leva-nos a uma primeira compreensão de que a alegria é paradoxal porque não nega a realidade do existir e, desta forma, apresenta-se como tensão a uma alegria ilusória nos termos de Rosset $(1989,2000)$. Esse, leitor de Nietzsche, resume em uma frase o conceito de alegria paradoxal, "Toda interpretação é delírio, sejamos felizes, tudo vai mal" (ROSSET, 1989, p. 8).

Dessa premissa, ao menos mais três compreensões se apresentam. a) A indiferença com a infelicidade. A alegria paradoxal é irracional no exato sentido de estar na contramão das discussões racionalistas de Platão a Heidegger. A razão de ser da alegria nem sempre pode ser comprovada, racionalizada, quantificada. b) A alegria é cruel. A alegria paradoxal é indiferente a qualquer outro sentimento. Ela é totalizante. Nada abala sua estrutura ao ponto de desfazê-la terminantemente. c) A alegria paradoxalé a loucura que salva a cada um de nós. A alegria paradoxal é a única loucura que evita todas e quaisquer outras loucuras.

A tradição filosófica de Platão a Heidegger coloca a alegria como fuga da realidade. Por isso, a noção de esperança é um marco desse pensamento que busca algo além da realidade. Na ótica da filosofia trágica - duplo da filosofia racionalista ou carnavalização da filosofia racionalista - a ação de negar a realidade é definida como neurótica.

No mito de Pandora, Hesíodo narra que, na caixa violada de Pandora, somente o recurso esperança ficou protegido. E ela era um veneno por ser o pior dos flagelos que leva os homens à espera. Hesíodo afirma que a esperança é um vício e não uma virtude, que é uma fraqueza e não uma força. Um sinal de falta de gosto pelo viver. Esse curto relato do mito de Pandora nos oferece um indício do pensamento trágico presente na mitologia grega. Nesse período de transição (séc. VIII - VII a.C.), entre o mito e a filosofia, a tragédia grega floresce como a força da razão e não a razão da força, ou seja, como liberdade do sujeito/herói se recusando a sucumbir aos desígnios divinos (destino) e fazendo uso de sua liberdade (escolha responsável, ato ético). 
Nesse sentido, corroboram as palavras de Rosset (2000, p. 29): "O homem da esperança é um homem sem recursos e argumentos, homem exausto, literalmente esgotado". Contrária à esperança é a alegria paradoxal, pois ela é a força maior. Essa força reside justamente no assumir a existência sem álibis. A teoria bakhtiniana do ato responsável e da carnavalização encontra-se com a filosofia trágica. E então o que é o trágico na perspectiva filosófica aqui assumida? Nietzsche (1987) nos diz em suas sentenças e setas de número 8, antes de começar o texto propriamente dito de Crepúsculo dos ídolos que, "na escola bélica da vida, o que não me mata, me fortalece" (NIETZSCHE, 1987, p. 2). $\mathrm{O}$ enunciado nietzschiano nos fala que tudo o que nega a efemeridade, o movimento, o jogo, a morte, os instintos é um pensamento não trágico e, portanto, para não perder a metáfora, é neurótico.

O pensamento não trágico perde, oculta ou silencia o caos/o acaso e dá lugar ao pensamento ontológico tradicional da linha de Platão a Heidegger. A defesa da alegria paradoxal ser a prática de uma existência sem álibis ganha fundamentação na teoria de Bakhtin. Esse nos diz: "ser realmente na vida significa agir, é ser não indiferente ao todo na sua singularidade" (BAKHTIN, 2010b, p. 99). Em outras palavras, uma reviravolta ontológica da noção de ser (ontos) como do existir, viver. Ou seja, existir é ser singular e dessa singularidade responder sem a criação de aparatos como, em nosso exemplo, a esperança, o otimismo. “O ato na sua integridade é mais que racional - é responsável. [...] a racionalidade é somente um momento seu, uma luz que é como um brilho de 'uma lâmpada em uma clara manhã' (Nietzsche)" (BAKHTIN, 2010b, p. 81).

O pensamento trágico na filosofia bakhtiniana reside no compreender a vida e os discursos como constantes embates de ideologias cotidianas e oficiais. O movimento, as inversões, a ruptura com o eu cartesiano "que se levanta pelos próprios cabelos" (BAKHTIN, 2006, p. 51), a perspectiva da alteridade como constituinte e o corpo grotesco são todas noções que se encontram familiares ao pensamento trágico. Não obstante, são as noções de ato responsável e carnavalização as mais íntimas da noção da alegria paradoxal.

A alegria que Bakhtin discute em A cultura popular na idade média - O contexto de François Rabelais (2010a, p. 35, grifo nosso) é a alegria paradoxal. Com suas palavras:

O motivo da máscara é mais importante ainda. É o motivo mais complexo, mas carregado de sentido da cultura popular. A máscara traduz a alegria das alternâncias e das reencarnações, a alegre relatividade, a alegre negação da identidade e do sentido único, a negação da coincidência estúpida consigo mesmo; a máscara é a expressão das transferências, das metamorfoses, das violações das fronteiras naturais, da ridicularização, dos apelidos; a máscara encarna o princípio de jogo da vida, está baseada numa peculiar 
- | A alegria paradoxal: o riso carnavalesco como filosofia trágica

inter-relação da realidade e da imagem, característica das formas mais antigas dos ritos e espetáculos. O complexo simbolismo das máscaras é inesgotável. Basta lembrar que manifestações como paródia, a caricatura, a careta, as contorções e as "macaquices" são derivadas da máscara. É na máscara que se revela com clareza a essência profunda do grotesco.

Com Bakhtin, assim como Nietzsche, a filosofia não medicinal é praticada. Mais precisamente, suas filosofias não trazem receitas prontas, não se aninham na ausência do duplo e do real. A profundidade reside, para ambos, na existência estética que é única e é produzida e produz a cultura, os sentidos e os valores. Por essa razão, não há nada de pessimismo na filosofia trágica. Ao dizer que o real é o aparente, que a máscara revela a profundidade de toda efemeridade e ambivalência, afirma-se que não há uma verdade e homogeneidade, que não há um mundo verdadeiro, mas sim relações, perspectivas, criação de sentidos a cada evento - o jogo, a relativização dos lugares e papéis.

Ter a consciência "libertada do domínio da concepção oficial" (BAKHTIN, 2010a, p. 239) ou ser como um "andarilho por ter se livrado do domínio da razão" (NIETZSCHE, 2013b, aforismo 638, p. 438) é ter uma lucidez lúdica que compreende a ausência de sentidos prontos e, dessa constatação, cada indivíduo se coloca em movimento criativo/ criador. $\mathrm{O}$ andarilho nietzschiano ou o sujeito consciente bakhtiniano é a pessoa que toma como causa o próprio caminhar, é a pessoa interessada no movimento, no embate discursivo, nas tensões entre as ideologias.

A imagem da queda é também, assim como a da máscara, propícia para a compreensão da alegria paradoxal, pois pode-se indagar: ao constatar a ausência de sentidos prontos, ao se ver livre e responsável, a resposta do sujeito é sempre a mesma? Não. Como sujeitos singulares, as respostas geradas serão a marca da singularidade de cada um de nós. Pode-se depois da queda - dessa nova consciência nascida de uma experiência - levantar-se e escolher ainda, por relações mecânicas, se sustentar sobre pretextos, desculpas, álibis. Mas pode-se, também, levantar-se com uma consciência trágica/carnavalizada. Essa queda existencial pode, por essa segunda opção, trazer um novo homem, um homem cuja existência é então assumida ética e esteticamente.

Bakhtin usa o exemplo da transferência do mundo para um único plano - o alto e o baixo tornam-se relativos - a ênfase se desloca para as noções de frente e atrás. Essa mudança de perspectiva faz com que toda hierarquia e unilateridade sucumbam "na medida em que a hierarquia não pode referir-se senão à existência firme, imóvel, imutável e não ao livre devir" (BAKHTIN, 2010a, p. 319). 
Da queda existencial, dessa inversão de valores ou transvalorização de todos os valores, desse sucumbir da hierarquia, a alegria paradoxal como a lucidez lúdica responde e responde sem álibis. A reviravolta que cada sujeito pode fazer em torno de si mesmo é a estética da criação de que fala Bakhtin no âmbito da vida. Nietzsche diria "faça de sua vida uma obra de arte" e, ambos, estão falando a partir de uma filosofia trágica, de um pensamento aberto ao movimento e ao jogo assim como às tensões culturais e ideológicas.

A força que se encontra nesse pensamento trágico que rompe com a identidade fixa e coesa é a situação ambivalente de destruição e destronamento associados à construção e renovação. Esse movimento de morte/vida no sentido de ser o gênero sempre novo encontra no riso, na alegria sua expressão máxima. Daí a insistência de Bakhtin, assim como de Nietzsche, em problematizar o riso. O riso defendido por esses pensadores nada tem de banal ou ilusório, em nada se associa ao menosprezo ou superioridade. Esse riso é a alegria paradoxal. Citando Rabelais, reafirma Bakhtin (2010a, p. 121): "Sorridente, a própria verdade se abre ao homem quando ele se encontra num estado de alegria despreocupada". Com efeito, a consciência liberta é a alegria despreocupada como uma forma ética-estética trágica de assumir a existência.

\section{Um breve tratado sobre o riso - em busca da alegria paradoxal}

Para pensar sobre o riso na sua dimensão de alegria paradoxal, Bakhtin usa a terminologia italiana "la grottesca". Derivado de grotta (gruta), pinturas encontradas nas cavernas na região da Itália do século XV eram abertas, inacabadas, híbridas num misto de animais, plantas e humanos, criando corpos estranhos à representação consensual do real. Sodré e Paiva (2004) afirmam que o grotesco associado ao disforme e ao onírico passa de um substantivo restrito à avaliação estética de obras de arte a um adjetivo a serviço do gosto generalizado. O filósofo Montaigne é talvez o primeiro a transportar o conceito de grotesco da pintura para as letras. No final do século XVII, grotesco passa a ser compreendido como ridículo e até burlesco. No século XVIII, o classicismo rejeita o grotesco por considerá-lo algo imaginado, sonhado, fantasioso, irreal, sem significado, de mau gosto, distante da inteligência e da verdade. No século XIX, é então definido como categoria estética. Todavia, a reflexão acerca do grotesco fica adormecida, conforme argumentam Sodré e Paiva (2004), despertando somente depois da segunda guerra (1939 a 1945) pelas obras A Cultura Popular na idade média de Bakhtin, em 1965, e o Grotesco de Kayser em 1957. 
- A alegria paradoxal: o riso carnavalesco como filosofia trágica

Bakhtin (2010a) afirma que as imagens grotescas procedem da época antiga: da mitologia e nas artes arcaicas de todos os povos, incluindo a arte pré-clássica dos gregos e romanos. Na época clássica, as imagens grotescas ficaram excluídas da arte oficial, mas vivas em domínios não canônicos, isto é, em domínios não determinados por regras, normas e proporções aplicadas à representação do corpo humano e animal. Mais precisamente, "o aspecto essencial do grotesco é a deformidade. A estética do grotesco é em grande parte a estética do disforme" (BAKHTIN, 2010a, p. 38).

Enquanto fenômeno, o grotesco é uma categoria ampla; há tanto a experiência do terror, do macabro, cruel e demente, como há a vivência do estranho, fabuloso, curioso e risível conforme se combinam os elementos, segundo as interpretações de Sodré e Paiva (2004). Tais combinações produzem efeitos artísticos diferentes. Para exemplificar recorrendo à cinematografia, tem-se, entre muitos outros, os filmes Crash - estranhos prazeres $^{2}$, Reflexões de um liquidificador ${ }^{3}$ e a animação Shrek ${ }^{4}$ como três diferentes expressões do grotesco. Nos exemplos citados, estão presentes modalidades expressivas (espécies) diferentes como o teratológico e o escatológico, ambos provocando o estranhamento, o espanto e até o riso através da ruptura com "a ordem normal das coisas": carros batidos, amassados e destruídos tornados objetos de prazer; o prazer em se ver à beira da morte - escatológico (Crash). Liquidificador que fala, mulher traída que liquidifica o marido escatológico (Reflexões de um Liquidificador). Monstro nojento, desajeitado e politicamente incorreto combinado com coração puro e engraçado - teratológico e risível (Shrek).

Para Bakhtin, o grotesco é compreendido como o que ele chama de realismo grotesco, definindo-se por sua relação intrínseca ao riso e ao cômico:

\footnotetext{
A orientação para baixo é própria de todas as formas da alegria popular e do realismo grotesco. Em baixo, do avesso, de trás para a frente: tal é o movimento que marca todas essas formas. Elas se precipitam todas para baixo, viram-se e colocam-se sobre a cabeça pondo o alto no lugar do baixo, o traseiro no da frente, tanto no plano do espaço real como no da metáfora. (BAKHTIN, 2010a, p. 325).
}

O realismo grotesco não fica restrito ao plano metafórico, antes é uma prática, uma atividade pela qual a vida é "debatida", diz Bakhtin, não nas igrejas ou nas escolas, mas na praça, em meio às brincadeiras e às distrações. É no cotidiano das relações, na cultura popular fomentadora da ideologia não oficial que relações de igualdade subvertem relações hierárquicas.

\footnotetext{
2 Direção de David Cronenberg, 1996 - USA.

3 Direção de André Klotzel, 2010 - Brasil.

4 Direção de Andrew Adamson e Vicky Jenson, 2001 - USA.
} 
O problema do grotesco e de sua essência estética só pode ser corretamente colocado e resolvido dentro do âmbito da cultura popular da Idade Média e do Renascimento. Para compreender a profundidade, as múltiplas significações e a força dos diversos temas grotescos, é preciso fazê-lo do ponto de vista da unidade da cultura popular e da visão carnavalesca do mundo; fora desses elementos, os temas grotescos tornam-se unilaterais, débeis e anódinos. (BAKHTIN, 2010a, p. 45).

O que significa dizer que o grotesco somente será bem compreendido se analisado a partir da cultura popular? E por que a cultura popular da Idade Média e do Renascimento são destacadas por Bakhtin?

Primeiramente, o grotesco é a base da teoria da carnavalização como defendemos. A atitude de inverter e deslocar não se separam, sem perdas, de um realismo grotesco. Mais precisamente, o grotesco, conforme apresenta Bakhtin, não tem uma perspectiva negativa que o limita às produções da cultura oficial, mas o problematiza apreciando a cultura popular:

\footnotetext{
Bakhtin, por outro lado, entende que a dificuldade em bem se avaliar o grotesco consistia em não se levar em consideração a criatividade da cultura popular. [...] seu livro [...] pretende exatamente corrigir o engano de seus antecessores, especialmente os românticos, que haviam concebido um "grotesco de câmara", ou seja, individualizado e sem carnaval. [...] na concepção apresentada pelo teórico russo, o grotesco não mais depende da noção de obra de arte. Sua principal categoria analítica é o realismo grotesco, que gira em torno do "corpo grotesco", isto é, uma corporalidade inacabada, aberta às ampliações e transformações... (SODRÉ; PAIVA, 2004, p. 57).
}

Não obstante, quando Bakhtin destaca a cultura popular é para opô-la não à cultura de elite e/ou erudita, mas a uma cultura oficial. Quanto às análises feitas sobre a Idade Média e Renascimento, Bakhtin (2010a) observa tensões nítidas trazendo à tona a dualidade de tudo, a ambivalência das relações. A ideologia oficial da Idade Média, de um lado com as proibições, hierarquias, seriedade e um corpo acabado chocavam-se com a ideologia cotidiana da liberdade e livre contato, do riso e do corpo incompleto, disforme e desestabilizador. Não obstante, a visão grotesca do corpo tem numerosas representações na filosofia humanista do Renascimento, segundo Bakhtin. O cosmos medieval estava constituído na noção aristotélica dos quatros elementos (água, fogo, ar e terra), inseridos numa hierarquia do alto e baixo pelo movimento de cada elemento em relação ao centro e ao cosmos. 
- | A alegria paradoxal: o riso carnavalesco como filosofia trágica

O que caracteriza o quadro do cosmos na Idade Média é a gradação dos valores no espaço; aos graus espaciais no sentido de baixo para cima correspondiam rigorosamente os graus de valor. Quanto mais elevada for a situação de um elemento na escala cósmica, mais ele se aproxima do "motor imóvel" do mundo, melhor ele é, mais perfeita é a sua natureza. Os conceitos e imagens relativos ao alto e ao baixo, na sua expressão espacial e na escala de valores, entraram na carne e no sangue do homem medieval. (BAKHTIN, 2010a, p. 319, grifo do autor).

Enquanto, no cosmos medieval, a relação entre o alto e baixo era hierárquica, no Renascimento esse quadro muda: o alto e o baixo são inseridos num mesmo plano e relativizados pela ênfase dada às noções de frente e atrás. Essa mudança na perspectiva pode ser lida como ponto de fuga, relativizando a oficialidade.

Essa transferência do mundo para um único plano, a substituição do vertical para o horizontal (com uma intensificação paralela do fator tempo), realizaram-se em torno do corpo humano, que se tornou o centro relativo do cosmos. Mas esse cosmos não se move mais de baixo para cima, mas para frente sobre a horizontal do tempo, do passado para $o$ futuro. No homem de carne a hierarquia do cosmos subverterase, abolira-se: o homem afirmava o seu valor fora dela. (BAKHTIN, 2010a, p. 319, grifo do autor).

É por essas tensões tão fortemente marcadas que Bakhtin lê as possibilidades transgredientes da cultura popular, afirmando que o riso da Idade Média venceu o medo, degradou o poder e seu porta-voz foi a figura do bufão.

As práticas carnavalescas próprias às festas populares em que todos são ativos, sem divisões entre atores e espectadores trazem à vista tudo o que está rebaixado e inversamente rebaixa tudo o que está nas alturas. Bakhtin viu nos carnavais de rua como as vestimentas características, injúrias, blasfêmias, contato familiar e brincadeiras colocavam o mundo de cabeça para baixo e, dessa forma, ressignificavam a vida.

\footnotetext{
A livre relação familiar estende-se a tudo: a todos os valores, ideias, fenômenos e coisas. Entram nos contatos e combinações carnavalescas todos os elementos antes fechados, separados e distanciados uns dos outros pela cosmovisão hierárquica extra carnavalesca. (BAKHTIN, 2011a, p. 141).
} 
Na obra de Rabelais, especialmente durante o Renascimento, Bakhtin encontrou a transposição do vocabulário, das imagens e formas da praça pública para a literatura.

No século XIX e XX, Bakhtin afirma um reaparecimento do grotesco em duas linhas. Uma ele chama de modernista, presente nos surrealistas e expressionistas. A outra linha é definida como realista e ele a encontra em Bertolt Brecht e Pablo Neruda, por exemplo. No século XIX, viu a carnavalização e o riso ambivalente como influência determinante na literatura e usa os escritos de Dostoiévski como exemplo. Pelo abandono do monologismo e a prática da igualdade de vozes entre autor e herói, Dostoiévski, segundo Bakhtin (2011a, p. 333), relativiza o estável e consegue adentrar as profundezas das relações humanas e da consciência do sujeito.

O todo final em Dostoiévski é dialógico. Todas as personagens centrais são participantes do diálogo. Escutam tudo o que as outras dizem a seu respeito e a todas respondem (sobre elas nada é dito à revelia ou a portas fechadas). E o autor é apenas um participante do diálogo (o seu organizador).

Em Bakhtin, a estética grotesca se opõe à noção de que a expressão artística está indissociavelmente ligada à representação do belo enquanto idealização do harmonioso, imortal e equilibrado. Mas também não é definido, como fez Victor Hugo, como contraponto ao sublime (BAKHTIN, 2010a). O grotesco bakhtiniano está intrinsecamente associado à cultura popular cômica e é compreendido como um realismo grotesco por seguir o princípio material e corporal, isto é, o rebaixamento de todas as coisas a um plano material e corporal. Não obstante, o grotesco romântico é criticado pela ausência do polo afirmativo.

\footnotetext{
No grotesco romântico, as imagens da vida material e corporal: beber, comer, satisfazer necessidades naturais, copular, parir, perdem quase completamente sua significação regeneradora e transformam-se em "vida inferior". As imagens do grotesco romântico são geralmente a expressão do temor que inspira o mundo e procuram comunicar esse temor aos leitores ("aterrorizá-los"). (BAKHTIN, 2010a, p. 34).
}

O polo afirmativo, portanto, está associado ao riso que surge das ações pelas quais o mundo é virado de cabeça para baixo. O riso carnavalizado ou popular organiza todas 
- | A alegria paradoxal: o riso carnavalesco como filosofia trágica

as formas do realismo grotesco. "O riso degrada e materializa" (BAKHTIN, 2010a, p. 18), é uma força, uma das poucas inalienáveis disponíveis à multidão.

O sério é o oficial, autoritário, associa-se à violência, às interdições, às restrições. Há sempre nessa seriedade um elemento do medo e da intimidação. [...]. Pelo contrário, o riso supõe que o medo foi dominado. O riso não impõe nenhuma interdição, nenhuma restrição. Jamais o poder, a violência e a autoridade empregam a linguagem do riso. [...]. Ao derrotar esse medo, o riso esclarecia a consciência do homem, revelava-lhe um novo mundo [...] ela podia formar para si uma verdade diferente, não oficial, sobre o mundo e o homem... (BAKHTIN, 2010a, p. 78, grifo do autor).

O riso é, para Bakhtin, de importância crucial. Associado às festividades, ritos, espetáculos e como manifestação coletiva de uma multidão, o riso tem o poder de transgredir a ideologia oficial.

As manifestações populares do período de junho a outubro de 2013 trazem mais exemplos do poder do riso transgressor. Na fotografia abaixo, manifestantes ironizam e ressignificam as relações ao transvalorizar o sentido das bombas de efeito moral fazendo, dessa forma, uma crítica à conduta de alguns dos representantes da população e à conduta policial de forma carnavalesca. 


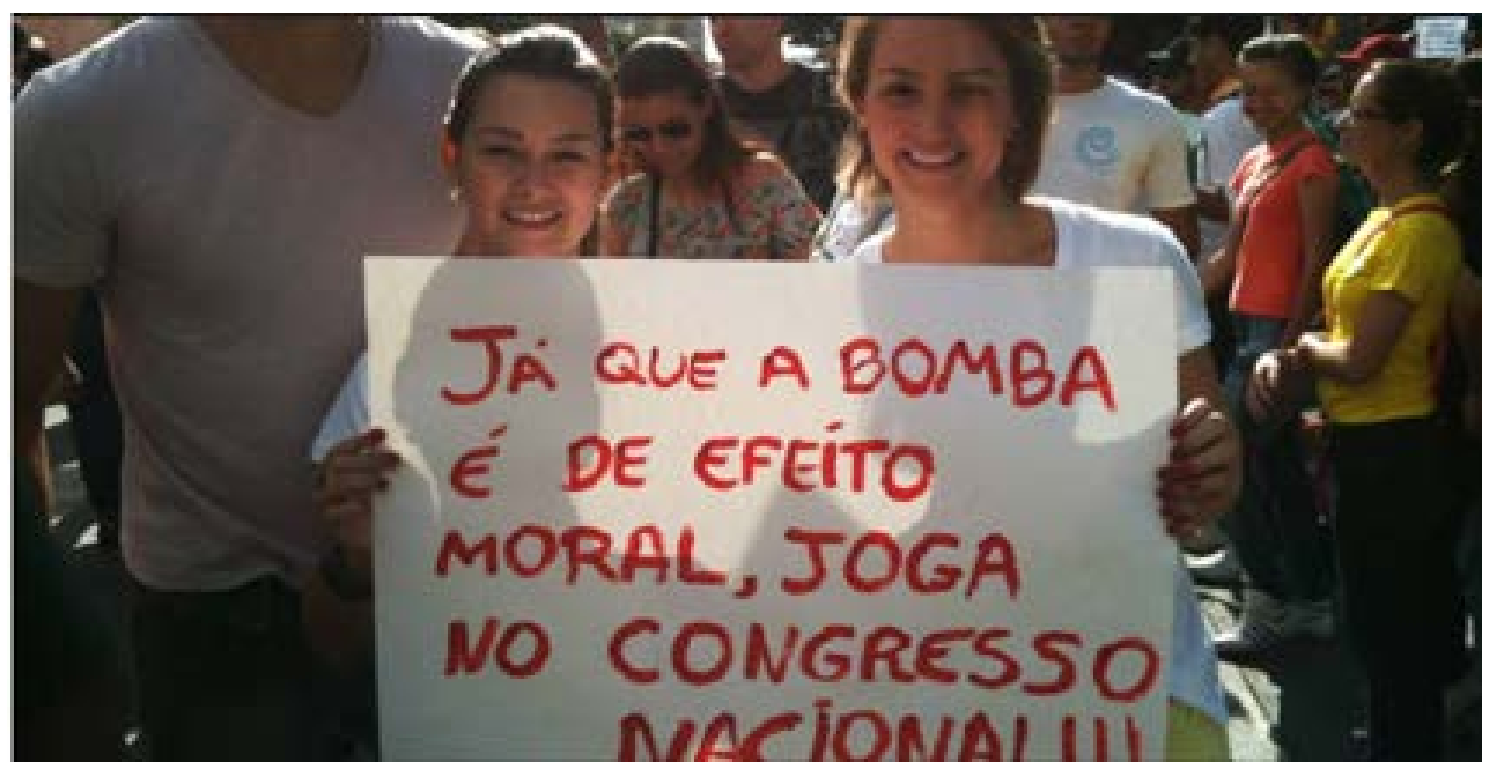

Figura 1 - Manifestações

Fonte: http://www.youcast.com.br/1014128/ja-q-a-bomba-e-de-efeito-moraljoga-nocongressovemprarua-acordabrasil-mudabrasil-changebrasil-semviolencia

O enunciado carregado em meio à manifestação popular é uma resposta a dois eventos ao menos. Primeiro, responde contra as formas de corrupção. Em segundo, responde ao excesso de força policial que, na tentativa de inibir as manifestações, usa de uma "violência pura" - os gases de efeito moral. A ironia e o deslocamento constituem o gênero carnavalesco e aparecem no enunciado. Em outros termos, diz o enunciado: "em vez de lutar contra a multidão, lute contra a corrupção".

O riso é uma posição estética determinada diante da realidade, mas intraduzível à linguagem da lógica, isto é, é um método de visão artística e interpretação da realidade e, consequentemente, um método de construção da imagem artística, do sujeito e do gênero. O riso carnavalesco ambivalente possuía uma enorme força criativa, força essa formadora de gênero. Esse riso abrangia e interpretava o fenômeno no processo de sucessão e transformação, fixava no fenômeno os dois polos da formação em sua sucessividade renovadora constante e criativa: na morte prevê-se o nascimento, na vitória, a derrota, na derrota, a vitória, na coroação, o destronamento, etc. O riso carnavalesco não permite que nenhum desses momentos da sucessão se absolutize ou se imobilize na seriedade unilateral. (BAKHTIN, 2011a, p. 189). 
- A alegria paradoxal: o riso carnavalesco como filosofia trágica

No espetáculo de humor Mais que Dilmais (2015), protagonizado por Gustavo Mendes, dentre várias imitações que esse artista protagoniza, uma delas é de destaque no trabalho do comediante e serve como exemplo do riso transgressor: a imitação da expresidente Dilma Rousseff.

Gustavo inicia dizendo que incorpora a presidenta. Por esse inicial desempenho, a hierarquia e distanciamento são quebrados sem ser ofensivo à pessoa da presidenta, talvez crítico a seus discursos e à figura de poder oficial. A plateia se vê diante da presidenta, visto que Gustavo, além de ter uma fisionomia muito parecida com ela, se fantasia de Dilma usando acessórios parecidos com os que ela usa em aparições públicas, vestindo um terninho muito semelhante e com o mesmo penteado. Com um linguajar completamente carregado de palavrões e performances, a "presidenta" conta e até canta seus feitos.

A reação é um riso generalizado, impossível, como diz Bakhtin, de não se entregar ao riso festivo. A presidenta é destronada: não tem mais traço nenhum de seriedade; discrição e distanciamento; estes são invertidos pelo exagero, tagarelice e proximidade.

Todavia, se relegado ao riso reduzido, o poder transgressor do riso festivo ou carnavalizado perde toda sua força regeneradora. Conforme Sodré e Paiva (2004), a degeneração do grotesco é encontrada em diferentes momentos, mas, no âmbito contemporâneo, essa degeneração pode ser localizada principalmente nos modelos de programas de auditório que usam o grotesco com a finalidade de compensar as angústias cotidianas através do riso cruel. Por essa perspectiva, a relação com o riso não tem nada de crítica e o grotesco aproxima-se do kitsch.

Como já colocava Bakhtin, se o elo com o polo afirmativo é perdido, a ação carnavalesca perde juntamente seu sentido utópico, crítico, transformador, questionador e criador e desboca numa experiência de terror, engano e tom lúgubre, degenerando-se. Uma primeira possibilidade de degenerar-se é quando sua ligação com a cultura popular é rompida. Uma segunda forma pela qual o grotesco se degenera é quando a festa se torna falsificação, produzindo uma estatização da vida. Uma terceira é quando o grotesco fica reduzido "ao cômico de baixa qualidade".

Um exemplo entre outros do cômico de baixa qualidade e com o propósito, a nosso ver, de compensar, como dizem Sodré e Paiva (2004), as angústias cotidianas através do riso cruel, pode-se ver geralmente em programas de "pegadinhas $5^{5}$.

51.Brasil [Televisão] Encenação filmada secretamente onde os participantes são surpreendidos com situações cômicas, constrangedoras, provocatórias ou insólitas. 2. [Brasil] Brincadeira que, por divertimento ou troça, se faz para iludir ou enganar alguém. Dicionário Houaiss (2011, p. 710). 
Como se pode problematizar, esse tipo de humor pouco acrescenta de afirmativo na constituição do sujeito; antes, parece-nos tornar os sujeitos mais competitivos, cruéis e reféns de uma lógica capitalista de um sistema toyotista para o qual ser alguém, ser valorizado é também não ser bobo de ninguém, estar 24 horas alerto, ser polivalente para não deixar nada passar despercebido.

O riso coletivo não se define por várias pessoas rindo umas das outras, mas sim várias pessoas juntas rindo de si mesmas. No caso das "pegadinhas", os telespectadores riem do outro porque o outro se deixou levar, não esteve atento o suficiente, "dormiu no ponto", foi pego. Não obstante, o verbo pegar, nesse contexto, nada tem a ver com ser contíguo, agarrar, transmitir e cativar, mas remete a um sentido figurativo de ser enganado, passado para trás; um humor neoniilista prenhe de uma indiferença pura.

Para Stam (2010), o riso "enlatado" é um exemplo do grotesco reduzido ao banal. Nesse sentido, o riso carnavalizado pode ser transformado num simulacro cuja função é paliativa, dando à sociedade debilitada uma sensação de festividade. "O riso enlatado da televisão se transforma no atraente substituto do riso real, que é possível apenas em uma atmosfera comunitária" (STAM, 2010, p. 338).

Rir individualmente de uma situação embaraçosa em que o outro fora colocado é o riso que a televisão, em geral, possibilita; o que não tem nada a ver com o riso grotesco - o riso comunitário - defendido por Bakhtin. Todavia, esse já apontava para o riso e a festa falsificados e, portanto, degenerados, ausentes de polo afirmativo.

\begin{abstract}
Nesta época (mais precisamente, desde a segunda metade do século XVII), assiste-se a um processo de redução, falsificação e empobrecimento progressivos das formas dos ritos e espetáculos carnavalescos populares. Por um lado, produz-se uma estatização da vida festiva que passa a ser uma vida de aparato; por outro lado introduz-se a festa no cotidiano, isto é, ela é relegada à vida privada, doméstica e familiar. Os antigos privilégios da praça pública em festa restringem-se cada vez mais. A visão do mundo carnavalesco, particular, com seu universalismo, suas ousadias, seu caráter utópico e sua orientação para o futuro, começa a transformar-se em simples humor festivo. A festa quase deixa de ser a segunda vida do povo, seu renascimento e renovação temporários. (BAKHTIN, 2010a, p. 30, grifo do autor).
\end{abstract}

Dois lados ao menos podem ser vislumbrados na relação do grotesco com o riso e o cômico: um afirmativo e um degenerado. O primeiro nascido de baixo para cima enquanto festividade comunitária e adversária à cultura oficial. O segundo enquanto 
- | A alegria paradoxal: o riso carnavalesco como filosofia trágica

imitação, cuja ordem é de cima para baixo, reafirma padrões preestabelecidos do belo, do correto e da verdade, ficando ausentes os princípios estéticos de transvalorização. Na contemporaneidade é o que permite o emergir de princípios degradados em forma do espetáculo de massa.

Se mantida a relação do grotesco com o riso regenerador, a experiência do grotesco pode ser entendida como contraposição aos padrões impostos do estético e politicamente corretos. A complexidade da natureza do riso carnavalesco, diz Bakhtin (2010a, p. 10),

\begin{abstract}
É, antes de mais nada, um riso festivo. Não é, portanto, uma reação individual diante de um outro fato "cômico" isolado. O riso carnavalesco é em primeiro lugar patrimônio do povo [...]; todos riem, o riso é "geral"; em segundo lugar, é universal, atinge a todas as coisas e pessoas [...], o mundo inteiro parece cômico e é percebido e considerado no seu aspecto jocoso, no seu alegre e cheio de alvoroço, mas ao mesmo tempo burlador e sarcástico, nega e afirma, amortalha e ressuscita simultaneamente.
\end{abstract}

Eis que, por essa perspectiva, a estética grotesca pode então ser compreendida como percepção crítica da realidade, ou seja, como subversão dos valores. Nesse momento, podemos compreender a alegria paradoxal. A alegria, por exemplo, que move participantes de um protesto, de uma festa como o carnaval e todas suas ressignificações não se reduz a uma relação alienante. De fato, a alegria que move as multidões ou a cada sujeito em sua luta diária é uma alegria paradoxal, como coloca Rosset (2002), pois uma alegria que reconhece a tragédia da existência sem, por isso, incidir no medo, no silêncio e na aceitação tranquila. Não é uma alegria ingênua ou pacífica; é uma alegria transformadora e engajada. Por isso, a alegria paradoxal ser uma prática do grotesco, ser o riso carnavalizado, ser a lucidez da consciência trágica, uma forma de vida e uma sensibilidade genuína.

O grotesco em Bakhtin é uma forma de refletir sobre a vida, ou seja, pensar rupturas e ressignificações pela perspectiva do grotesco enquanto um outro estado de consciência ou, nas palavras de Rosset (2000), uma força maior. Nietzsche diria a beatitude da vida, ou seja, uma adesão para com a existência sem remorsos, sem desculpas.

Toda nova atitude, pensamento e ação geram respostas e são respostas a um conjunto de enunciados. Essa é a arena instaurada pela palavra encarnada, pelo responder ético e responsável. Tais relações, portanto, são tensas, conflitantes e não tranquilas e estagnadas. Mais precisamente, as ações de transgrediência como atos responsáveis 
individuais, festas ou protestos não se resumem a ações moralmente estabelecidas e preconcebidas. Elas escapam a toda ordem. Transgridem tais fronteiras. Por isso, todo acabamento só pode ser um momento efêmero. Nos termos que Rosset (2000) toma de Nietzsche, a superfície é o que há de mais profundo, daí tudo o que é profundo gostar de máscaras. A máscara tem duas funções: uma é dizer a eterna insuficiência da palavra enquanto verdade; a segunda é função de pudor, pois dissimula e oculta uma riqueza, um ainda por vir, um projeto de dizer.

Todo ato responsável, individual ou coletivo, carrega também um realismo grotesco: um exagero nas ações, uma exibição rude e grotesca do corpo, das palavras e das relações. Mais precisamente, a alegria, o regozijo total dos sujeitos num determinado espaço de tempo, não se associa à alienação. Antes e fundamentalmente, a alegria defendida como transgrediência é paradoxal. Ou a alegria é ilusória, Bakhtin diria a festa oficial, ou ela é paradoxal. Ilusória quando nega a realidade - o trágico da existência. Paradoxal quando há um acordo do sujeito com a existência que, ao reconhecer sua tragédia, vive a alegria paradoxal.

\begin{abstract}
Não é surpreendente que eu dê preferência ao segundo termo da alternativa, persuadido não somente que a alegria consiga acomodarse com o trágico, mas, ainda e, sobretudo, de que ela consista apenas neste e por este acordo com ele. Pois justamente o privilégio da alegria e a razão do contentamento singular, porque o único a não ter reservas, permanecer a um só tempo perfeitamente consciente e perfeitamente indiferente acerca das infelicidades que compõem a existência. Essa indiferença à infelicidade não significa que a alegria seja desatenta a ela, menos ainda que pretenda ignorá-la, mas ao contrário, que é iminentemente atenta, a primeira interessada e a primeira concernida; isso devido precisamente a seu poder aprovador que lhe permite conhecer a infelicidade mais e melhor do que ninguém. Por isso direi em uma palavra que só há alegria se ela é ao mesmo tempo contrariada e se está em contradição com ela mesma: a alegria é paradoxal ou não é alegria. (ROSSET, 2000, p. 25).
\end{abstract}

Mas o que é o trágico? Mais precisamente, o que é uma filosofia trágica? Sem uma decorrência direta com o pensamento moderno sobre a tragédia, a filosofia trágica é o pensar pelo acaso. Rosset (1989) define o acaso como o não significado, o sentido que ainda não existe, não está predado. Em outras palavras, é o pensamento que compreende que os sentidos existem ao serem criados. A história da Filosofia ocidental, salvo exceções, se desenvolvera com a recusa de pensar o acaso. Anaxágoras diz que no início era o caos; depois vem a inteligência que arruma tudo. Todavia, a ordem revelada não 
- A alegria paradoxal: o riso carnavalesco como filosofia trágica

é necessariamente uma perspectiva dialógica, mas um ocultar o caos - a desordem, o efêmero, o movimento. "O sabor da existência é o do tempo que passa e muda, do não fixo, do jamais certo nem acabado; aliás, a melhor e mais certa "permanência" da vida consiste nessa mobilidade (ROSSET, 2000, p. 20).

Bakhtin enfatiza ao falar da carnavalização como o triunfo do novo e do devir. Diz ser o riso carnavalesco capaz de lançar um novo olhar, uma consciência liberada da seriedade banal e repleta de uma nova seriedade que livre e lúcida ri. Ri e faz pouco do temível, da ordem do de cima e do de baixo; inverte tudo, põe em jogo, muda a perspectiva e transforma em alegre espantalho toda seriedade patética.

\section{Para não concluir}

O sujeito que reconhece a precariedade da existência, que percebe a fragilidade do ego ensimesmado, que aprende que uma só voz nada termina, que sabe que a única loucura que o salva das outras é a alegria e que esta não pode ser quantificada, pois é momentânea e efêmera; que aprende que a crueldade da alegria é ser totalizante dela nada escapando, esse é o sujeito que assume a existência trágica, esse é o sujeito que não se amedronta diante do oficial, não se estagna com o otimismo e com a esperança, este é o sujeito que age, faz seu ato responsável, faz um acordo com a existência. Esse é o sujeito bakhtiniano - o portador da alegria paradoxal; o riso carnavalesco é sua força maior, seu pensamento trágico.

\section{Referências}

BAKHTIN, M. A Cultura popular na idade média e no renascimento: o contexto de François Rabelais. 7. ed. São Paulo: Hucitec, 2010a[1965].

Para uma filosofia do ato responsável. São Carlos: Pedro \& João editores, 2010b[1920-1924].

Estética da criação verbal. 4. ed. São Paulo: Martins Fontes, 2006[1979].

Problemas da poética de Dostoiévski. 5. ed. Rio de Janeiro: Forense Universitária, 2011[1929]. 
NIETZSCHE, F. Assim falava Zaratustra - um livro para todos e para ninguém. v. 1. São Paulo: Escala, 2013a. (Coleção O essencial de Nietzsche).

Humano demasiado humano. v. 9. São Paulo: Escala, 2013b. (Coleção O essencial de Nietzsche).

O nascimento da tragédia. v. 7. São Paulo: Escala, 2013c. (Coleção O essencial de Nietzsche).

NIETZSCHE, F. Crepúsculo dos ídolos - ou como filosofar com o martelo. In: Nietzsche Os pensadores. v. II. São Paulo: Nova Cultural, 1987.

PROTESTOS pelo Brasil. Fotografia de Fernando Torres. Youca.st - Protestos - cobertura colaborativa dos protestos. 24 jun. 2013. Disponível em: <http://www.youcast.com. br/1014128/ja-q-a-bomba-e-de-efeito-moraljoga-no-congressovemprarua-acordabrasilmudabrasil-changebrasil-semviolencia>. Acesso em: 29 jun. 2015.

ROSSET, C. Alegria - a força maior. Rio de Janeiro: Relume Dumará, 2000.

Lógica do pior. Rio de Janeiro: Espaço e tempo, 1989.

SODRÉ, M.; PAIVA, R. O império do grotesco. Rio de Janeiro: MAUAD, 2004.

STAM, R. Bakhtin: da teoria literária à cultura de massa. São Paulo: Ática, 1992.

COMO CITAR ESTE ARTIGO: SILVESTRI, Kátia Vanessa Tarantini. A alegria paradoxal: o riso carnavalesco como filosofia trágica. Revista do GEL, v. 15, n. 1, p. 178-194, 2018.

Disponível em: https://revistadogel.gel.org.br/.

DOI: http://dx.doi.org/10.21165/gel.v15i1.1837

Submetido em: 18/05/2017. | Aceito em: 20/02/2018. 